\title{
Aesthetics in Theatre: The Challenge of Effect Under the Skin
}

\section{Guilherme Filipe ${ }^{1}$ (1)}

'Researcher Dr., University of Lisbon, Faculty of Fine Arts and Humanities, Theatre Studies Centre, Lisbon, Portugal

\section{ORCID: G.F. 0000-0001-7425-9937}

Corresponding author / Sorumlu yazar: Guilherme Filipe,

University of Lisbon, Faculty of Fine Arts and

Humanities, Lisbon, Portugal

E-mail/E-posta: jmorafilipe@sapo.pt

Submitted/Başvuru: 10.03.2021

Revision Requested/Revizyon Talebi:

13.04.2021

Last Revision Received/Son Revizyon:

13.04.2021

Accepted/Kabul: 16.04 .2021

\section{Citation/Atıf:}

Filipe, Guilherme. "Aesthetics in Theatre: The Challenge of Effect Under the Skin" Tiyatro Eleştirmenliğive Dramaturii Bölümü Dergisi 32, (2021): 75-94

https://doi.org/10.26650/jtcd.894645

\section{ABSTRACT}

The tremendous socio-political transformations that took place in the 19th century contributed to the change of criterion for theatre dramaturgy during the following century. The essence of the history of theatre, as "liminal space", based on traditional perspectives of theatre illusion and dramatization of identity crisis suffered a profound revolution due to the decay and loss of essential values, thus leading to the emergence of the "theatre of the 'new' man". This essay presents a panoramic view of ways of comprehending aesthetics along the 20th century. Through the work of many outstanding authors on this matter, our modernity is brought to understand that the dramaturgy of mankind will go on being the dramaturgy of theatrical performance, as a form of Art, being the transubstantiation of an ordinary world into a transcendent world of signs. Keywords: $20^{\text {th }}$ century, Avant-garde(s), Western Dramaturgies, Aesthetics, Theatre Studies 


\section{Introduction}

From Aristotle's Poetics to the end of the eighteenth century, the arousal of passions, feelings, and affects denoted the commonly desired effect of theatrical performances within the wider framework of the aesthetics of effect. ${ }^{1}$

According to professor Fischer-Lichte, the great transformation of paradigm in the European theatre in the 20th century was due to the displacement of the importance attributed to the dramatic text to the importance attributed to the text displayed on stage. ${ }^{2}$ The History of European Drama and Theatre (1990) contributes to structure the essence of theatre history, as "liminal space", from the neoclassical and medieval "ritual theatre", through the Theatrum Vitae Humanae of the Renaissance and Baroque, to the modernity of the "rise of the middle class and appearance of the theatre of illusion" 3 and the "dramatization of identity crisis", ${ }^{4}$ the decay and loss of essential values of which led to the emergence of the "theatre of the 'new' man". ${ }^{5}$ Although the attention to the discovery of the audience's role is focused on a German perspective, the phenomenon manifested itself in different ways throughout the Western world, according to local cultures, with a desire for experimentation. Its origin can be found in the great socio-political transformations that took place in the nineteenth century and continued through the following century. In Portugal, the painter and poet Almada Negreiros (1893-1970), in A Invenção do Dia Claro (1921, Inventing a Clear Day), expresses the same principle of paradigmatic change after World War I, stating that we do not belong to a "century that invents", but to a century that reinvents the use of what has been invented. When quoting Rimbaud - le monde n'a pas d'âges, l'humanité se déplace tout simplement-Almada expresses his concern over searching for the essence of new things - saluons la naissance $d u$ travail nouveau. In the search for an artistic purity, in the first half of the twentieth century, research was oriented towards the construction of aesthetics, while in the second half it sought the elaboration of poetics that defined the founding aesthetics - nous savons donner notre vie toute entière tous les jours - and motivated future fractures. Thus said, let us ask in what way the concept of spectacle and its manifestations changed throughout the evolutionary process in the twentieth century.

In classical dramaturgy, the term spectacle was synonymous with what is now considered as staging:

1 Erika Fischer-Lichte, The Transformative Power of Performance: A New Aesthetics (London/New York: Routledge, 2008), 150-151.

2 See Erika Fischer-Lichte, The Show and the Gaze of Theatre: A European perspective (Iowa: University of Iowa Press, 1997).

3 Erika Fischer-Lichte, History of European Drama and Theatre (London/New York: Routledge, 2002) 146.

4 Ibid., 202.

5 Ibid., 284. 
The Spectacle has, indeed an emotional attraction of its own, but, of all the parts, it is the least artistic, and connected least with the art of poetry. For the power of Tragedy, we may be sure, is felt even apart from representation and actors. Besides, the production of spectacular effects depends more on the art of the stage machinist than on that of the poet. ${ }^{6}$

Here is the anathema thrown on the spectacular form. In the name of Truth, Art was intended to be a product of Rationality, which the Spectacle did not possess, because it depended on the reinterpretation of the didaskalos, a director, whose logical interpretative discourse would have to approach the emotional logical discourse of the spectator. Euripides did not neglect this characteristic in the writing of his tragedies despite the precepts of the Greek Stagirite.

This attitude of distrust was perpetuated through successive reinterpretations of Aristotle, for different reasons, always renewed, throughout the Western world. Frequently, the so-called literate socio-professional elites, more than the general public, who are illiterate, behave in a paternalistic way, if not hostile to the spectacle, or individual performance, that does not lead them to the good port of obvious understanding. And yet what the spectacle means is as important as what the spectator feels it means. One should not expect the spectacular production to explain what the reception should do, i.e., to be imbued with the dynamics of the spectacle. Neither should it close itself, creating an attitude of intellectual arrogance and blaming the receiver for inability to comprehend a non-existent communication.

Against what was regarded as the accommodating attitude of the spectator rose the theatre artistic elites at the beginning of the twentieth century. For creators as Vsevolod Meyerhold (1874-1940), the stage acted as a barrier between the spectator and the actor, thus dividing the theatre into two equally alien worlds - those who acted and those who watched. It became necessary to build a bridge over the orchestra pit in order to bring the two sides together, drama and reality, scene and realness. Without ever neglecting the text, but abolishing its literary characteristic, Meyerhold reflected on the theatricality while writing the scene. The concept of staging led to an understanding of the need for a dramaturgy, i.e., a work that harmonized the understanding of the text through the performance of the actors who inhabit the space of the scene, a pretext of the spectacle itself, thus gaining the right of his freed life. ${ }^{7}$ According to Picon-Vallin, it is a theatre of a "scientific era" that originated a theatre of a "technological era" of today. ${ }^{8}$

Antonin Artaud (1896-1948), in Le théâtre et son double (The Theatre and his Double, 1938), considered the spectacle as a hinged point of representation, which allowed it to enlarge

6 Aristotle, The Poetics of Aristotle (London: Macmillan, 1902), 29-30.

7 See Jean Weisberger. Les avant-gardes littéraires au XXe siècle (Amsterdam/ Philadelphia : John Benjamin, 1984).

8 Béatrice Picon-Vallin, "Vers un 'super-acteur'?", in Etudes théâtrales, L'acteur entre personnage et performance 26 (2003), 59-68. 
the physical space in all possible planes, to work in different degrees of perspective, and added the notion of time and movement. According to Roland Barthes (1915-1980), the spectacle became a universal category through which the world could see itself, thus ending up being all that is offered to the eye, with so much to be shown and seen, as demonstrated by the creative technique of Erwin Piscator (1893-1966). This extension of the concept of spectacle implied that it would no longer be considered only as the representation of a dramatic text, but would include other forms of scenic representation - dance, opera, cinema, mime, circus - or other activities involving the participation of the public - sports, rites, cults, social interactions. The cultural performances that ethnoscenology currently deals with aim to extend the study of theatre to the spectacular practices of the whole world, especially those that have their origin in the rite and ceremonial practices. In this sense, we can speak of the need for a dramaturgy of the actor himself, which organises all the expressive elements and the techniques of work to optimise the interpretive quality. The individual work that is generated constitutes itself as a form of laboratory according to experimentalist forms as opposed to those of art as a vehicle, by Jerzy Grotowski (1933-1999), Peter Brook (b. 1925) or Eugénio Barba (b. 1936).

However, when G.W. Hegel (1700-1831) recommended the free circulation of manuscripts in theatres, he was consciously laying the foundations for an emancipation of dramatic art through the spectacle, i.e., staging the drama. Hegel believed that the concept of Beauty could be objectively and rationally identifiable. ${ }^{9}$ Hegelian aesthetics belongs to the philosophy of the spirit, to the philosophy of art without any metaphysical pretension, in the creation of the idea of artistic beauty, always superior to the natural, because it is a production of the spirit, a perfect harmony between form and content. Being a concept in the absolute essence, it is subject to gradual evolution in time and geographical space. The static principle of idealised beauty gives way to the dynamic principle of a self-conscious subjectivity, which is an important factor for the realisation of the spirit and evolution of human history.

On the Art of Theatre (1911), Edward Gordon Craig (1872-1966) reaffirmed the same idea, being the theatre "so exceptional a place"10. "First and foremost comes the scene"11.

The Art of Theatre is neither acting, nor the play, it is not scene nor dance, but it consists of all the elements of which these things are composed: action, which is the very spirit of acting, words, which are the body of the play; line and colour, which are the very heart of the scene; rhythm, which is the very essence of dance. ${ }^{12}$

Therefore, the art of theatre, which for centuries had been essentially logocentric, and dependent on literary criticism, since the end of the eighteenth century and throughout the nineteenth, widened its horizons, not only in theoretical debate but also on staging a play.

9 See Guilherme Pires Ferreira, "O conceito de Belo em geral na Estética de Hegel: Conceito, ideia e verdade",

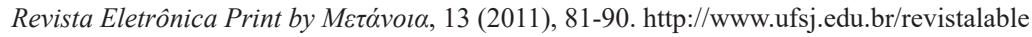

10 Edward Gordon Craig. On the Art of Theatre (London: William Heinemann, 1911), xi.

11 Ibid., 22.

12 Ibid., 188. 
Therefore, the art of theatre, which for centuries had been essentially logocentric, and dependent on literary criticism since the end of the eighteenth century and throughout the nineteenth, widened its horizons not only in theoretical debate but also on staging a play.

What is a spectacle? A minimal theoretical definition may indicate that from an internal point of view, it is characterised by the existence of a three-dimensional space where a subject/ actor voluntarily produces senses to be received in an external space by a subject/spectator who willingly decodes the initial senses and establishes mental synapses of the issued images. According to a fictional statute, we can define the spectacle as an art of fiction which seeks to create its own reality distinct from the referential reality (theatre, non-documentary cinema, opera, mime, etc.) or as a nonfictional art, a performance built on dexterity, strength or skill (circus, bullfighting, soccer, etc.). ${ }^{13}$

The concept of spectacle gained strength due to the deep and revealing reasons which design the theatrical activity where everything has a significant value: text, scene and the auditorium itself. Space becomes a global object, and the spectacle is no longer confined to the restricted space of the stage, projecting itself out of it and the theatre building itself, into the city, thereby increasing its framing. ${ }^{14}$ The subjectivity of the dramatic production, which is confined to the intimacy of the author's space, gains objectivity through the plastic materialisation of the mediating space of the spectacle to provoke intersubjectivities among audiences and societies.

Secondly, traditional forms are renewed with new means and new techniques, new approaches of expression in which everything is placed at the service of the theatre. ${ }^{15}$ Finally, theatre gains autonomy vis-à-vis the public, in the same way, that an adolescent emancipates himself from his paternal guardianship. No longer needed the illusion of reality only to satisfy the taste of those who wish to rejoice and delight in the illusory happiness of soap operas. Manufacturing processes are exhibited, or they are integrated as the skeleton under the flesh of performance, emotions are released, the sensibility and sensuality of the theatrical game is clearly brought to the surface of theatrical discourse without the fixation with globalising signifiers. The desire for total freedom led to the creation of theatrical aesthetics freed from traditional conventions,

13 Political rallies, even if they have a spectacular form, are sometimes difficult to define, for the more or less blatant character of elocutory communication: sometimes they seem fiction, sometimes less so. However, they are always cultural performances like any event destined to massive audiences.

14 Note the impact that open space performances, such as the street theatre, or the intervention theatre like the Schlingensief produce both in the spectators and in the criticism.

15 Note that in the urban space of Lisbon, theatrical structures, such as Paula Sá Nogueira's Teatro Cão Solteiro, Ricardo Neves-Neves's Teatro do Elétrico, Joana Craveiro's Teatro do Vestido, Monica Calle's Casa Conveniente, Bruno Bravo's Primeiros Sintomas, or Ricardo Teixeira and Ivo Silva's Silly Season collective, among other artistic-cultural enterprises carry out experiments in search for new dramaturgies with a creative attitude either based on everyday life situations or on the dramatic tradition. 
as done by Free Stages, Free Theatres ${ }^{16}$ or People's Theatres, ${ }^{17}$ creating other conventions of novelty, also transforming the utopias of life into stage aesthetics.

The great motivation of creators such as Erwin Piscator (1893-1966), ${ }^{18}$ Vsevolod Meyerhold (1874-1940), ${ }^{19}$ Vladimir Mayakovsky (1893-1930), ${ }^{20}$ Bertolt Brecht (1898-1956), ${ }^{21}$ Samuel Beckett (1906-1989), ${ }^{22}$ and many others lingered in his followers either consciously or unconsciously both in form and content in the search for an aesthetic response to the great questions of life.

But what is Aesthetics? A science under one's skin, made of sensibility? Two complementary meanings present themselves. On the one hand, etymology points to its Greek origin (aesthesis), a sensibility either in the realm of perception or in the sensitive aspect of our affectivity. On the other hand, and in a current context, it designates any philosophical reflection on Art. And since Theatre is a form of art, it does not escape the judgment of Aesthetics as a spectacular object, as Drama did not escape the judgment of Poetics as a literary object.

In the history of aesthetics, we can distinguish three evolutionary ages:

1. Dogmatism, from Socrates to Alexander Gottlieb Baumgarten (1714-1762), in 1750,

2. Criticism, which leads from Immanuel Kant (1724-1804) to the post-Kantians, Johann Gottlieb Fichte (1762-1814) ${ }^{23}$ and Friedrich von Schelling (1775-1854), ${ }^{24}$ and to the infinite freedom of the Self,

16 Die Frei Bühne (1889), in Berlin, supervised by Otto Brahm, inspired by André Antoine's Théâtre-Libre (1887), in Paris, and Jacob Grein's Independent Theatre Society (1891), in London, were subscription-based theatres which inspired the Independent Theatre Movement. They shared the same purpose of giving performances of plays which had literary and artistic rather than commercial values.

17 Maurice Pottecher's Théâtre du Peuple (1895), in Bussang (France) or the Freie Volksbühne (1890), in Berlin, depict a general movement towards the democratization of the theatre, opening the stage and auditorium to the masses, portraying people and the actions of a people, as stated by Romain Rolland in his essay Le Théâtre du Peuple (1913).

18 Erwin Piscator, The Political Theatre. A History 1914-1929 (London: Methuen, 1980).

19 See Marjorie L. Hoover, Meyerhold: The art of conscious theatre (Massachusetts: University Press, 1974). Edward Braun, The Theatre of Meyerhold: Revolution and the Modern Stage (Iowa: University Press, 1995).

20 See Bengt Jangfeldt, Majakovsky and futurism 1917-1921 (Stockolm: Almqvist \& Wiksell International, 1976).

21 See Bertolt Brecht \& John Willett, Brecht on theatre: the development of an aesthetic (New York: Hill and Wang, 1964). Peter Buse, “Archaeology of an acting style: Stanislavski, Brecht and the subject”, European Journal of Cultural Studies 2, (1998).

22 See Dirk van Hulle, A new Cambridge companion to Samuel Beckett (Cambridge: Cambridge University press, 2015).

23 His original insights into the nature of self-consciousness or self-awareness motivate much philosophical cogitations, like Descartes and Kant before him, about the problem of subjectivity and consciousness.

24 Friedrich von Schelling, Vorlesung über die Philosophie der Kunst (Lecture on the Philosophy of Art). The Philosophy of Art; An Oration on the Relation between the Plastic Arts and Nature, trans. A. Johnson (London: John Chapman, 1845). 
3. Positivism, from 1850 on, marked by the development of the human sciences and the desire to extirpate the sequels of the metaphysical spirit.

Thanks to the work of Friedrich Nietzsche (1844-1900), Art develops its own language, its own conventions, in short, the autonomy capable of opening the way to the expression of desire. It is a new aesthetic that incites creation, instead of seeking the essence of Beauty, which evolves from romantic pessimism to the global affirmation of the world of art (Dionysus - Zarathustra), and inspired the Wagnerian manifestations.

According to L'Esthétique (1961, Aesthetics), by Denis Huisman (b. 1929), in this third phase, and on until day, we find four important currents of interest to us, in their individual specificity: (1) “positivist", (2) “idealist," (3) “critical” and (4) "libertarian". 25

$* * *$

\section{Positivist Aesthetics}

In my concept- that I formed with beauty and joy-there is but one art: the art that arouses infinite and ineffable sensations, intese and very pleasant soul and moral emotions. ${ }^{26}$

In a similar way to the scientific approach, positivist aesthetics pretend to use a rigorous methodology so that the work of art is apprehended through a non-intuitive discursive language that fills the space between the production and reception of the work of art, that is, between the artist and the cultural epistemology in which his work emerged. The world of forms and their genesis can be explained, and art can be formalised as any knowledge of any age. The existence of an experimental aesthetic systematises an objective character and establishes a normative code, which demonstrates the work of art as the product of a medium, of a moment and an origin. It is a model in which the objective essence of Beauty is conceptually determined on the basis of experience and direct induction "from underneath" (von unten) in the opinion of the German philosopher Gustav T. Fechner (1801-1887) in his Vorschule der Aesthetik (Introduction to Aesthetics). ${ }^{27}$

Inspired by Espinosa (1632-1677) for whom matter and spirit were inseparable, Fechner establishes a psychophysical parallelism, creating the Weber-Fechner's law, i.e., a method that is capable of interconnecting a measurable physical quantity with an inexplicable intimate personal sensation. Although highly speculative, the theory intends to demonstrate the existence of a relation of scientific greatness between a stimulus and the production of a sensation. It concludes thus that the scale of the stimuli can be represented by a geometric progression,

25 Denis Huisman, L'Esthétique (Paris: Presses Universitaires de France, 1954).

26 J. Cano-Ruiz, "As emotividades e o sentimento humano da Arte", A Batalha 115, 5-6.

27 Gustav Theodor Fechner, Vorschule der Aesthetik (Leipzig: Breitkopf, 1876). 
being the sensation of a logarithmic intensity of the stimulus. In his search for definition of Beauty and its components, Fechner attempted to develop parameters for fundamental notions of Gefallen/Misfallen (pleasing/ displeasing), Lust/ Unlust (desire/ indifference), and to the traditional categories of Schön (beautiful), Gut (good) and Wahr (truth), he added Werth (value) and Interesse (interest), thus establishing a practical distinction between an aesthetic sense and Aesthetics.

Linguistics also contributed to the development of positivist aesthetics. Ferdinand de Saussure (1857-1913) in Cours de Linguistique Général (1906-11, Course in General Linguistics) ${ }^{28}$ created a mathematical system for language and its use, introducing rigorous methods of analysis, and Benedetto Croce (1866-1952) in Estetica come scienza dell'espressione e linguistica generale (1908, Aesthetics as Science of Expression and General Linguistic) ${ }^{29}$ sought to demonstrate that aesthetics was a "general linguistic" and an "expression of expression".

Strongly influenced by Hegel's and Schelling's German idealism, Croce created a Philosophy of the Spirit in which he seeks to resolve the traditional dichotomy between empiricism and rationalism, between sensationalism and transcendentalism through the new concept of immanence, the immanemtism, product of life experience of the human being in a given space and time. Reality is the product of an existence inherent to a concrete experience, an argument that Croce exposes in works such as Materialismo Storico ed Economia Marxista (1900, Historical Materialism and the Economics of Karl Marx), ${ }^{30}$ Logica come scienza del concetto puro (1909, Logic as a science of the pure concept) and Filosofia della Pratica: Economica ed Etica (1909, Philosophy of the Practical: Economics and Ethic) ${ }^{31}$

In the iconographic field, the German-Jewish art historian Erwin Panofsky (1892-1968) in Die Perspektive als symbolische Form (1927, Perspective as Symbolic Form) ${ }^{32}$ in which he adapts the concept of the philosopher Ernst Cassirer (1874-1945) considered that at the base of artistic manifestations, beyond its meaning as a phenomenon and as meaning, there was a modern and essential content: the involuntary and unconscious self-revelation of a fundamental attitude towards the world, and hence the highest task of interpretation was to penetrate in the essential sense. ${ }^{33}$ For Panofsky, the History of Art was a science that defined three key

28 Ferdinand de Sausurre, Cours de Linguistique Générale (Lausanne/ Paris : Payot, 1916) ; Course in General Linguistics, trans. W. Baskin (Glasgow: Fontana/ Collins, 1977).

29 Benedetto Croce, Aesthetics as a science of expression and general linguistics, trans. Douglas Ainsle (London: MacMillan, 1909).

30 First edition in Bari: Gius. Laterza \& Figli, 1909. English edition: Historical Materialism and the Economics of Karl Marx. (Whitefish, Montana: Kessinger, 2004).

31 English edition: Philosophy of the Practical Economic and Ethic, trans. Douglas Ainsle (London: MacMillan, 1913).

32 English edition: Perspective as Symbolic Form, trans. Christopher S. Wood (New York: Zone Books, 1991).

33 Also see by the same author: Idea: A Concept in Art Theory (1924), Studies in Iconology (1939), Meaning in the Visual Arts (1955). 
moments of the interpretative act: a phenomenological reading of the perceived image, an interpretation of its iconographic meaning, and an understanding of the essential content as an expression of values. Although defined in relation to painting, Panofsky's theory can be applied to the theatre as an object that can be analysed both by Fine Arts and Fine Letters, being their point of intersection.

In Studies in Iconology, Panofsky clearly distinguishes the concepts of iconography and iconology, of image and its meaning - their ensemble creates a sign - and underlines the importance of understanding everyday behaviour for the understanding of its symbolic representation. Nothing more appropriate for the interpretation of the aesthetics of the theatrical act and the work of the actor as exhibitor of theatrical signs. Similarly, the three levels of understanding of art history as he advocates can be applied to the reception of theatrical act and understanding of what is observed. From the primary level (iconography), the most natural, which only perceives the work in its pure state, the audience passes to the secondary level (conventional), which adds the importance of cultural knowledge in a deeper interpretation of the previous level, to reach the intrinsic (content/ iconology), which requires the knowledge of factors external to the work itself. The theatrical act can be described as a broad interpretation of senses and the interpretive extrapolation of the initial image.

Susanne Langer (1895-1985) ${ }^{34}$ presents a controversial position. Equally influenced by Cassirer, Kant, or Ludwig Wittgenstein (1889-1961), for this American philosopher, the iconic symbol had to stand for itself and not just for the message it supposedly conveyed. Along with Cassirer, she shares that symbolic thought is inherent in the human being, and necessary for the evolution of knowledge in which Art is a creation of symbolic forms of human feeling. The work of art does not reveal the artist's emotional experience, but only his idea of emotion. In Feeling and Forms: A Theory of Art (1953), Langer discourses that theatre is a special poetic form that builds the existence of an intersection of the two great realms of the imagination: past and future. The dynamics of dramatic action do not reflect a concrete experience, but registers a narrative process of a story that is being told, and will only be understood when the performance reaches the end and the spectator understands the whole idea that was being told through each moment of the action. Dramatic action would be nothing more than a "concealed form" of a "virtual story" that opens up to the spectator.

The idea that art is a language the structural system of which can be studied opens the way for the investigation in semiotics of the Bulgarian-French philosopher and sociologist Tzvetan Todorov (1939-2017), of the French semiotician Roland Barthes (1915-1980) or the

34 An Introduction to Symbolic Logic (1937), Philosophy in a New Key: A Study in the symbolism of Reason, Rite and Art (1942), Feeling and Form: A Theory of Art (1953), Problems of Art: Ten philosophical lectures (1957), Reflections on Art (1958), Mind: An Essay on Human Feeling (1967 - 1982) and The Great Shift: Instinct to Intuition (1971). 
engineer of acoustics Abraham Moles (1920-1992) who studied the relationship between stage and audience, and formalised the processes of aesthetic reception of artistic phenomena. ${ }^{35}$ The positivist aesthetics support the problem plays, i.e., didactic plays, the kitchen sink realism, and, in general, the plays that are considered to be part of the theory of communication in the line of Barthes who also attributes a concept of functionality.

\section{Idealistic aesthetics}

In this case, the understanding of the phenomena of creation, understanding and interpretation will be made through the transcendence of subjectivity, using intuition, the study of essence, the reflexive method and the use of meanings without having to go through the decoding of any of the social sciences.

Among those who defended idealistic aesthetics is the philosopher Etienne Souriau (1892$1979)^{36}$ for whom aesthetics would be a science of forms under universal appearances, being the work of art an element of a universe unique to itself. Like philosophy, art aims to position those the existence of which is self-legitimated, insofar as art alone can express the inexpressible. In La Correspondance des Arts: Eléments d'Esthétique Comparée (1947), Souriau established a "system of Fine Arts", according to seven groups: (1) Sculpture or Architecture, (2) Drawing, (3) Painting, (4) Drama music or pure music, (5) Pantomime or Dance, (6) Literature and Poetry, (7) Cinema and Photography. All of them possessed sensory characteristics - phenomenon and cause -, and each class was capable of producing two levels of artistic object: presentational and representational.

This perspective allows the definition, in the case of theatre, in two opposing ways of expressing the relationship between the actor and the audience: the presentational acting and the representational acting. The first dialogues are directly with the audience, because the actor acknowledges its presence while the latter deliberately creates a barrier between himself and the audience, which is ignored in a studied way, and treated as voyeurs. For Robert Weimann:

Each of these theatrical practices draws upon a different register of imaginary appeal and "puissance" and each serves a different purpose of playing. While the former derives its primary strength from the immediacy of the physical act of histrionic delivery, the latter is vitally connected with the imaginary product and effect of rendering absent meanings,

35 Communications et langages (in collaboration with Vallancien) (Paris, Gauthier-Villares, 1963); Créativité et méthodes d'innovation (Paris : Fayard, 1970); Psychologie de l'espace (in collaboration with Élisabeth Rohmer) (Paris: Casterman, 1972); Théorie de l'information et perception esthétique (Paris : Denoël, 1973).

36 He was the son of university professor of Philosophy Paul Souriau (1852-1926) who studied the aesthetics of movement - L'Esthétique du mouvement, (1899) - and defined two distinct levels of beauty: mechanical beauty as significant, and expression of movement as meaning to the observer. Regarding his study of aesthetics to which he dedicated himself at the beginning of the $20^{\text {th }}$ century, see La suggestion dans l'art (1893), L'imagination de l'artiste (1901), La rêverie esthétique (1906), Traité de la beauté fonctionnelle (1910), ou L'esthétique de la lumière (1913). 
ideas, and images of artificial persons' thoughts and actions. But the distinction is more than epistemological and not simply a matter of poetics; rather it relates to the issue of function. ${ }^{37}$

The dramatic convention created narrative devices - prologue, epilogue, theatre-withintheatre, or the asides - to force the relationship between stage-audience: actor-actor, and actorspectator. These effects with metadramatic and metatheatrical function enhance the fictional nature of characters at the very moment of their representation and their true facticity:

[Language] is used in the I-you exchange to indicate or ostend, to refer to and, in general terms, to create the dramatic macro- and micro-contexts. But what takes place between the participants in the communicative event is constitutive of the drama in another crucial sense. The speech event is, in its own right, the chiefform of interaction in the drama. The dialogic exchange, that is, does not merely (...) refer deictically to the dramatic action but directly constitutes it. The proairetic (or 'action') dynamic of the play is carried, above all, by the intersubjective force of discourse. ${ }^{38}$

Representational acting fits into naturalism or psychological realism, and has led to the elaboration of representation methodologies such as the Stanislavski system, and the techniques of stage directors as André Antoine (1858-1943) ${ }^{39}$ in France, Otto Brahm (1856-1912) ${ }^{40}$ in Germany, Jacob Thomas Grein (1862-1935) $)^{41}$ in Great Britain, or Sanford Meisner (1905$1997)^{42}$ in the USA. The presentational acting is closely linked to the Epic Theatre developed by Bertolt Brecht (1898-1956), Vsevolod Meyerhold (1874-1940), to the Documentary Theatre by Erwin Piscator (1893-1966), or to the Theatre of the Oppressed by the theatre practitioner Augusto Boal (1931-2009) in Brazil. While the representational acting aesthetics intends to portray the human being in his environment in a behaviourist manner, the presentational acting aesthetics seek to intervene in political issues and claim a place of public debate for the theatre in politics. Through the theatre, one learns from the past and prevents future repetitions of previous political catastrophes.

However, the issue with idealistic aesthetics is that they tend to see art from a conservative perspective. On the one hand, they protect certain artistic and moral values, on the other, they enclose, in an essential value or in a timeless law, anything that only aspires to be metamorphosed. ${ }^{43}$ Souriau is as important as the linguists Vladimir Propp (1895-1970), A. J.

37 Robert Weimann, “Author's Pen and Actor's Voice: Playing and Writing in Shakespeare's Theatre”, in Cambridge Studies in Renaissance Literature and Culture, Ed. Helen Higbee and William West (Cambridge: Cambridge University Press, 2000) 11.

38 Keir Elam, The Semiotics of Theatre and Drama (London/ New York: Routledge, 1980), 96.

39 Founder of the Théâtre-Libre, in Paris, in 1887.

40 Founder of Die Freie Bühne, in Berlin, in 1889.

41 Founder of the Independent Theatre Society, in London, in 1891.

42 Founder of the Meisner/Carville School of Acting, in 1983, and The Sanford Meisner Center for the Arts, in 1995.

43 Huisman, L'Esthétique, 96. 
Greimas (1917-1992) or Roland Barthes in the elaboration of actantial models. These will lead to new interpretations of the dramatic text through dialectical readings of the dramaturgical functions. The paths of actions are traced according to diachronic analysis while the character's depth is sought using synchrony analysis, roaming every level, or layer of reality from general to specific perspective. Actor-director Antoine Vitez (1930-1990) used to say that when directing an actor, at the very moment of uttering a word, his interest would immediately shift to the word itself. Instead of interpreting the situation, he would rather go for the ideality that the situation inspired in him, becoming the dream triggered by the words in him as an actor and a person. This defines the notion of an orally delivered language in which the elocutory act becomes a hermeneutic act which combines the notions of volume, vocal colouring, and corporality. His proposal for the building up of stage direction is inherent to the interrelation of the written drama and its oral expression:

\begin{abstract}
Il s'agit chez le pédagogue ou le metteur en scène de susciter l'état d'ouverture, l'état de divination, l'état médiumnique qui consiste à se mettre en relation avec la mémoire enfouie, la mémoire indicible, la mémoire inavouable. C'est seulement comme cela que les acteurs peuvent faire des choses extraordinaires. (...) Diriger les acteurs, c'est rarement de la direction justement. C'est de les observer et leur restituer l'image qu'ils produisent déjà eux-mêmes, donc les rendre conscients de l'image qu'ils construisent. Il m'est très souvent arrivé de travailler vraiment à partir de l'aléatoire; de la présence brute des acteurs, même d'acteurs ne sachant pas que la répétition avait commencé. Me trouvant à l'extérieur je les observe et quelquefois, en les regardant vivre dans l'espace, je transforme en fiction ce qui est naturel. ${ }^{44}$
\end{abstract}

\title{
Critical Aesthetics
}

Though critical aesthetics' goal is to save the utopia of art, it eventually tends to be identified with the object which gave rise. With the decline of transcendence, rationality dominates the twentieth century, art becomes the critical embryo, and production totalitarianism settles in advanced industrial societies. Walter Benjamin (1892-1940), Theodor W. Adorno (1903-1969) and Herbert Marcuse (1898-1979) stand out as critical exponents of aesthetics, all of them belonging to the Frankfurt School.

Born in a German Jewish family, Benjamin endorsed his socialist ideals in his teens, as part of the German Free Youth Movement, and strongly influenced by Nietzsche's ideas. The

44 It is a matter for the pedagogue or the director to arouse the state of openness, the state of divination, the mediumistic state of putting oneself in relation with the buried memory, the unspeakable memory, the unavowable memory. Only then can actors do extraordinary things. (...) To direct actors, it is rarely a question of precise direction. It is to observe them and to restore to them the image they already produce themselves, thus making them aware of the image they are building. I have often worked really from randomness; the raw presence of the actors, even of actors not knowing that the repetition had begun. Finding myself outside I observe them and sometimes, watching them live in space, I transform into fiction what is natural. Antoine Vitez, André Curmi, "La 'direction d'acteur'”, Théâtre/Public 64-65, (juillet 1985), 23; Sophie Proust, La direction d'acteurs dans la mise en scène théâtrale contemporaine (Paris: L'Entretemps, 2006) 72. 
interest in Marxism, which he shared with Theodor Adorno, brings him closer to the philosophy of Georg Lukács (1885-1971). His ability to harmonise German idealism with dialectical materialism and Jewish mysticism constituted his stance on aesthetic theory. In his essay of cultural criticism, Das Kunstwerk im Zeitalter seiner technischen Reproduzierbarkeit (1935, The Work of Art in the Age of Mechanical Reproduction ${ }^{45}$ ), Benjamin enunciates the first materialist theory of art. The artwork had lost its aura, destroyed by the exchange value, the art market and the mass reproduction of the original object. Reproduction had broken the privilege of class to favour the character of exchange. It is nonetheless a paradoxical claim to the conservation of individualistic values when he criticizes the falsity of idealistic discourses about art. The era of the massification of the arts begins from the moment that there are technical resources that reproduce the work of art to reach the largest number of people through the mass media. And what is a mass work? Is it an art made by the masses such as crafts or any popular activity? Is it an art created for the masses by a minority? Or is it a modern technology (radio, television, or other means of communication)?

As sociologist, psychologist, musician and aesthetic critic, Adorno is concerned with the preservation of the individual and the work of art as an irreducible individuality, given the amount of existing bureaucratic and mercantile totalitarianism. His writings- Dialektik der Aufklärung (1944, Dialectic of Englightenment $)^{46}$, Negativ Dialektik (1966, Negative Dialectic $)^{47}$ and Aesthetische Theorie (1970, Aesthetic Theory) ${ }^{48}$ - are fundamental to the understanding of his philosophical perception, based on dialectics and psychoanalysis, which depend on the historical context of World War II and the US- Soviet bipolarization policy. For Adorno, the whole of the ideological system is not the fulfilment of the Spirit, but its death. The Dialectic of Enlightenment, written in collaboration with Marx Horkheimer, criticises the cultural logic of the capitalist system, the "cultural industry", the aim of which is centred on technical progress regarded as authoritarianism over the other. Adorno opposes the Hegel-inspired dialectic to admit irrational thinking, thus valuing art and problematic avant-garde art as forms of independence from instrumental reason. Since art is a mediated reflection of reality, artistic language would serve to express the irrationality, paradox and difference in which each work of art would be the bearer of its own world without constituting itself as a mirror of external reality. The supposed "best of all worlds" Aldous Huxley (1894-1963) or George

45 Walter Benjamin, "The Work of Art in the Age of Mechanical Reproduction" (1936), in Illuminations: Essays and Reflections, trans. Harry Zohn, Ed. Hannah Arendt (New York: Schocken Books, 1968), 217-252. Walter Benjamin, "The task of the Translator", in Illuminations: Essays and Reflections, trans. Harry Zohn, Ed. Hannah Arendt (New York: Schocken Books, 1968), 69-82. Walter Benjamin, The Origin of German Tragic Drama, trans. John Osborne (Verso, 2003).

46 Theodor W. Adorno \& Max Horkheimner, Dialetic of Enlightenment, trans. Edmund Jephcott (Stanford: Stanford University Press, 2002).

47 Theodor W. Adorno, Negative Dialectics, trans. E. B. Ashton (New York: Seabury Press, 1973).

48 Theodor W. Adorno, Aesthetic Theory, trans. R. Hullot-Kentor (Minneapolis: University of Minneapolis Press, 1997). 
Orwell (1903-1950) liquidated the individual, the singular and the subjectivity. However, the reality of art bears witness to the possibility of the existence of another conceivable reality. In the dramaturgy, the traditional logical coherence is broken, the narrative ruptures and the distancing modes, the aesthetics of discontinuous and fragmentation are provided. The viewer is asked to intervene in the creative process, reconstituting the puzzle of meanings and giving the aesthetic procedure an ideological meaning.

For Herbert Marcuse, ${ }^{49}$ critical reflection goes through the utopia of a non-repressive civilisation of which ethos would be beauty rather than rationality, where work would become a game, where eros, the drive for life, freed from the yoke of income and profit, would sublimate sexuality into free creations. In 1932, when Karl Marx's earliest writings were published, Ökonomisch-Philosophische Manuskripte aus dem Jahre 1844 (Economic and Philosophical Manuscripts of 1844), Marcuse found in The Paris Manuscripts both a critique of the effects of bourgeois capitalism on human life and a proposal of a new model of social organisation, carrier of quality of life without alienations. Marcuse would be the only Frankfurt School philosopher who would carry forward the revolutionary spirit of critical theory, "holding together philosophy, social theory and radical politics". ${ }^{50}$

The adverse political ambience in Germany led Marcuse to immigrate to the United States. He arrived in 1934 and received citizenship six years later. In the post-war period, Marcuse devoted himself to his academic career, rejecting Marx's theory of class struggle and criticising capitalist society in works such as Eros and Civilization (1955) in which he synthesises Marx and Freud, and One-Dimensional Man (1964) in which he criticizes not only contemporary capitalism, but also communism in the Soviet Union.

In Eros and Civilization, Marcuse conveys Freud's idea of the pursuit of happiness. In his preface, he admits that if society was not based on unbridled production and consumption, the use of wealth and knowledge could enhance the quality of life and prevent their destructive wills of people. Man would be more available to fully live according to his needs if he worked less and if the socio-political system had not developed perverse forms of effective control of society. The production of superfluous goods redefines forms and needs for society's pleasure. This concept will be developed in One-dimensional Man in which Marcuse declares that the progress of industrial society has led to the reversal of the role of bourgeoisie and proletariat from which agents of social history have become advocates of the status quo.

In the 1970s, Marcuse discovered a new sensitivity in certain youth groups (marginal student minorities) and in some artistic movements in the United States, thus perceiving the consequence

49 Christopher Holman, Politics as radical Creation: Herbert Marcuse and Hannah Arendt. (Toronto/ London: University of Toronto Press, 2013). Daniel J. Flynn, Intellectual Morons: How Ideology Makes Smart People Fall for Stupid Ideas (New York: Crown Forum, 2004).

50 Isabel Maria Loureiro (org.), Herbert Marcuse: A grande recusa hoje (Petrópolis: Vozes, 1999) 7. 
of a structural mutation in perception and action without which it would be impossible to achieve or perpetuate any social change. Attaching importance to the work of art rather than provocative exhibitions constituted his critique of Marxist idealism, and made him the mentor of the May '68 movement. Both An essay on liberation (1969) and the Counter-revolution and Revolt (1972) denounce the totalitarian role of modern industrial society and explore the existence of possibilities for human liberation through a counterrevolution which goes against Western totalitarianism and the massacres in Asia and Africa. Marcuse emphasises the role of art, literature and music as revolutionary forms that are capable of creating an aesthetic model of intervention, which corresponds to the practice of German school playwrights and stage performers, such as Peter Handke (n. 1942), R. W. Fassbinder (1945-1982) or Heiner Müller (1929-1995), among others.

\section{Libertarian Aesthetics}

While previous aesthetics maintained the division between subject and object, between ideal and real, libertarian aesthetics became categorical proclaiming the liberation of desire and the imaginary. Nature presents itself as an overflowing reality of force into which Man would enter through the idea of a wild perception. From the traditional principles of nature, inspiration and spontaneity, Mikel Dufrenne (1910-1995) associated the pleasure of creativity and utopian practices. His existentialist view of Art was influenced by Karl Jaspers (18831969) and Paul Ricoeur (1913-2005).

In Phénoménologie de l'expérience esthétique (1953, The Phenomenology of Aesthetic Experience), ${ }^{51}$ Dufrenne "proposes to trace the specificity of aesthetic experience vis-à-vis other modes of human relationships in the world". ${ }^{52}$ The artwork and aesthetic object are distinct concepts explained by intentionality. The former is a product of the artist's activity while the latter is defined by the aesthetic experience which in turn defines the former. In Esthétique et Philosophie (1976, Aesthetic and Philosophy), "affinity" and "intentional pact" are defined by a relationship not only between creator and work of art - it is contained in it, as result of its intentionality - but also in the privileged relationship established in the observer's aesthetic experience when "rethinking the subject of intentionality". ${ }^{53}$ The event that stimulates life will be the work of art, because happiness, fantasy or even madness are introduced into it. A happening, a party, the sign art, the pop concepts, and the body art are artistic objects in which art challenges itself. Each action relocates the space of reflection to a non-conventional area without field compartmentalisation to revive aesthetics, change perspectives, clash "bourgeois"

51 Mikel Dufrenne, The Phenomenology of Aesthetic Experience. trans. Edward S. Casey (Evanston: Northwestern University Press, 1973).

52 Eunice Pinho, “A Estética de Dufrenne ou a Procura da Origem”, Revista Filosófica de Coimbra 3/6 (1994), 361.

53 Ibid., 364. 
concepts, and assume new artistic arguments. By replacing representative systems with matrices of creativity, an artist expands the concept of Art rather than defines it or retain essences and artistic ideals. Thinking is also an art, ergo agitprop.

If theory empties itself, the exaltation of individualism is remarkable. Art is no longer a matter of individual taste, a way of pleasing, a reason for consensus, nor of common rules that lead to theorising. The meaning is obtained from the observation of the process in which the absence of style, the lack of syntax, and of grammaticality are the system rules; language is worth for what it stimulates - desire - rather than what it means - "a process and not an end, a production and not an expression":

Discoursing about art tends to bring together art discourse, and aesthetics to become programs. (...) Meaning is timeless, and Time is meaningless. ${ }^{54}$

\section{Concluding and moving forward to a new age}

What will be done? What paths will the 21 st century propose in terms of art perspectives?

It seems that what intentionality expressed by Almada Negreiros almost a century ago extends over time as the perpetuum mobile of existential relativity. And if all roads lead to Rome, common sense asserts, then, after this panoramic view of ways of understanding Aesthetics we feel that our modernity will remain pointing us to the ways leading to Art, at the same time to artistic product and fruition by the maker, the spectator, the critic, the seller, the buyer, the collector, the copycat, the copyist, the counterfeiter, by a myriad of glances, perspectives and intentions, i.e., the "constitutive feature of consciousness". 55

Is the concept complex, or human nature complicates it?

In relation to human nature, there are those who consider Art as imitation, those who consider it as entertainment, and those who understand it as manufacturing artwork. Divergence becomes consensual when it is assigned the duty to transfigure, to surpass reality by the use of idealisation: a reality seen and corrected by man who reappears in it as a transformed concept and a transforming element. The realistic scene, which is deceptively thought to be real, will always be more idealistic than veristic. As Aristotle would say: "poetry is truer than history". Once more we return to the starting point, stating that in the beginning there was the Word, the verbum, therefore the logos. The artistic recreation of the world is pure invention which needs human deep intelligence when referring to Art. Without the dramaturgy of mankind, there will not be a dramaturgy in theatrical performance. This presents itself as a transposition of reality, of the referent, through specific forms. In essence, we are dealing with

54 Huisman, L'Esthétique, 69.

55 Pinho, "A Estética de Dufrenne ou a Procura da Origem”, 364. 
the transubstantiation of an ordinary world into a transcendent world, transposing everyday reality into a suprareal reality that the aesthetic experience establishes as an autonomous practise in which a criterion corresponding to the degree of transfiguration can be defined: the less natural, the more artistic, the less trivial, the more global art. The metaphysics of art history will not fail to expose an evolutionary eclecticism that admits all arts and schools according to an elementary process. Art will, therefore, continue to idealise the best of all worlds, even if by antinomy. As a stylisation of the real, it will continue to promote existence, the creation of forms, beyond the mere production of beauty through the works of a Conscious Being in a permanent oscillation among positivist, idealist, critical and libertarian models according to the cultural degree of the societies that consume them in this so-called globalised world. And we will not be much mistaken if, despite the changing paradigms of each time, the essence of the discussion of Beauty and Truth through the spectacular form of the Arts remains what Baudelaire (1821-1867) felt in his time:

Le beau est toujours, inévitablement, d'une composition double, bien que l'impression qu'il produit soit une. (...) Le beau est fait d'un élément éternel, invariable, dont la quantité est excessivement difficile à déterminer, et d'un élément relatif, circonstanciel, qui sera, si l'on veut, tour à tour ou tout ensemble, l'époque, la mode, la morale, la passion. Sans ce second élément, qui est comme l'enveloppe amusante, titillante, apéritive, du divin gâteau, le premier élément serait indigestible, inappréciable, non adapté et non approprié à la nature humaine. Je défie qu'on découvre un échantillon quelconque de beauté qui ne contienne pas ces deux éléments. ${ }^{56}$

Peer-review: Externally peer-reviewed.

Conflict of Interest: The author has no conflict of interest to declare.

Grant Support: The author declared that this study has received no financial support.

Hakem Değerlendirmesi: Dış bağımsız.

Çıkar Çatışması: Yazar çıkar çatışması bildirmemiştir.

Finansal Destek: Yazar bu çalışma için finansal destek almadığını beyan etmiştir.

56 Inevitably, beauty is always of a double composition, although the impression that it produces is one. (...) Beauty is made of an eternal, invariable element, the quantity of which is exceedingly difficult to determine, and of a relative, circumstantial element, which will be, if you will, in turn, or together, the epoch, fashion, morality, passion. Without this second element, which is like the amusing, titillating, appetizing envelope of the divine cake, the first element would be indigestible, invaluable, unsuitable, and inappropriate to human nature. I challenge anyone to discover any beauty sample that does not contain these two elements. Charles Baudelaire, "Le beau, la mode et le bonheur", Le Figaro. (10e année - 916, 26.11.1863) 1-2. 


\section{BIBLIOGRAPHY / KAYNAKÇA}

Adorno, Theodor W. \& Horkheimmer, Max. Dialetic of Enlightenment, translated by Edmund Jephcott. Stanford: Stanford University Press, 2002.

Adorno, Theodor W.. Aesthetic Theory, Translated by R. Hullot-Kentor Minneapolis: University of Minneapolis Press, 1997.

Adorno, Theodor W.. Negative Dialectics, Translated by E. B. Ashton. New York: Seabury Press, 1973.

Aristotle. The Poetics of Aristotle. Translated by S. H. Butcher. 3ed edition revised. London: Macmillan, 1902.

Baudelaire, Charles, "Le beau, la mode et le bonheur", Le Figaro 916 (26.11.1863), 1-2.

Benjamin, Walter, "The task of the Translator." In Illuminations: Essays and Reflections. Translated by Harry Zohn. Edited by Hannah Arendt. New York: Schocken Books, 1968, 69-82.

Benjamin, Walter, "The Work of Art in the Age of Mechanical Reproduction." In Illuminations: Essays and Reflections. Translated by Harry Zohn. Edited by Hannah Arendt. New York: Schocken Books, 1968, 217-252.

Benjamin, Walter. The Origin of German Tragic Drama, Translated by John Osborne. Verso books, 2003.

Braun, Edward. The Theatre of Meyerhold: Revolution and the Modern Stage. Iowa: University of Iowa Press, 1995.

Brecht, Bertolt \& Willett, John. Brecht on theatre: the development of an aesthetic. New York: Hill and Wang, 1964.

Buse, Peter, "Archaeology of an acting style: Stanislavski, Brecht and the subject", European Journal of Cultural Studies, 2 (1998), 219-238.

Cano-Ruiz, J., "As emotividades e o sentimento humano da Arte", A Batalha 115, 5-6.

Craig, Edward Gordon. On the Art of Theatre. $5^{\text {th }}$ ed. London: William Heinemann, 1911.

Croce, Benedetto. Aesthetics as a science of expression and general linguistics, Translated by Douglas Ainsle. London: MacMillan and Co, 1909.

Dufrenne, Mikel. The Phenomenology of Aesthetic Experience, Translated by Edward S. Casey. Evanston: Northwestern University Press, 1973.

Elam, Keir. The Semiotics of Theatre and Drama. London/ New York: Routledge, 1980.

Fechner, Gustav Theodor. Vorschule der Aesthetik. Leipzig: Breitkopf, 1876.

Ferreira, Guilherme Pires, "O conceito de Belo em geral na Estética de Hegel: Conceito, ideia e verdade",

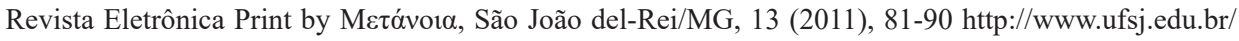
revistalable.

Fischer-Lichte, Erika. History of European Drama and Theatre. Translated by Joe Riley. London/ New York: Routledge, 2002 [ $1^{\text {st }}$ ed. 1990].

Fischer-Lichte, Erika. The Show and the Gaze of Theatre: A European perspective. Translated by Joe Riley. Iowa: University of Iowa Press, 1997.

Fischer-Lichte, Erika. The Transformative Power of Performance: A New Aesthetics. Translated by Saskya Iris Jain. London/New York: Routledge, 2008.

Flynn, Daniel J. Intellectual Morons: How Ideology Makes Smart People Fall for Stupid Ideas. New Yor: Crown Forum, 2004.

Holman, Christopher. Politics as radical Creation: Herbert Marcuse and Hannah Arendt. Toronto/Buffalo/ London: University of Toronto Press, 2013. 
Hoover, Marjorie L. Meyerhold: The art of conscious theatre. Massachusetts: University of Massachusetts Press, 1974.

Huisman, Denis. L'Esthétique. Paris : Presses Universitaires de France, 1954.

Hulle, Dirk van. A new Cambridge companion to Samuel Beckett. Cambridge: Cambridge University press, 2015.

Jangfeldt, Bengt. Majakovsky and futurism 1917-1921. Stockolm: Almqvist \& Wiksell International, 1976.

Loureiro, Isabel Maria (ed.), Herbert Marcuse: A grande recusa hoje. Petrópolis: Vozes, 1999.

Picon-Vallin, Béatrice, "Vers un 'super-acteur'?" In Etudes théâtrales, L'acteur entre personnage et performance 26 (2003), 59-68.

Pinho, Eunice, "A Estética de Dufrenne ou a Procura da Origem", Revista Filosófica de Coimbra V.3, 6 (1994), 361-396.

Piscator, Erwin. The Political Theatre. A History 1914-1929. Translated by Hugh Rorrison. London: Eyre Methuen, 1980.

Proust, Sophie. La direction d'acteurs dans la mise en scène théâtrale contemporaine. Paris: L'Entretemps, 2006.

Saussure, Ferdinand de. Cours de Linguistique Générale. C. Bally et A. Sechehaye (ed.). Lausanne/ Paris: Payot, 1916.

Saussure, Ferdinand de. Course in General Linguistics. Translated by W. Baskin. Glasgow: Fontana/ Collins, 1977.

Schelling, Friedrich von. The Philosophy of Art; An Oration on the Relation between the Plastic Arts and Nature. Translated A. Johnson. London: John Chapman, 1845.

Vitez, Antoine \& Curmi, André, "La 'direction d'acteur”, Théâtre/Public 64-65 (juillet 1985).

Weiberger, Jean. Les avant-gardes littéraires au XXe siècle. Amsterdam/ Philadelphia: John Benjamin publishing Company, 1984.

Weimann, Robert, “Author's Pen and Actor's Voice: Playing and Writing in Shakespeare's Theatre", in Cambridge Studies in Renaissance Literature and Culture. Edited by Helen Higbee and William West. Cambridge: Cambridge University Press, 2000. 
